\title{
The health profile of newly-arrived refugee women and girls and the role of region of origin: using a population-based dataset in California between 2013 and 2017
}

\author{
May Sudhinaraset ${ }^{1 *}$, Nuny Cabanting ${ }^{2}$ and Marisa Ramos ${ }^{2}$
}

\begin{abstract}
Background: There has been an increasing number of refugee women globally; yet, there is little recent data describing the health profile of refugee women by region of origin in the United States. It is important to monitor the health status of women by region of origin to provide needed targeted interventions.

Methods: We analyzed the Refugee Health Electronic Information System (RHEIS), a population-based dataset that included 14,060 female refugees who entered California between October 3, 2013 and February 15, 2017. We assessed differences in health status by region of origin.

Results: Almost one out of three women experienced a traumatic event. Women from Africa and Latin America and the Caribbean experienced higher levels of trauma compared to other regions, including sexual assault, physical, and weapon assault. More than half of women and girls (56.6\%) reported experiences of persecution, with Southeast Asians reporting the highest levels. Among women of reproductive age, $7.0 \%$ of women were currently pregnant at the time of arrival to the US, 19.0\% ever had a spontaneous abortion, and $8.6 \%$ reported ever having an abortion. One in three women from Africa reported female genital cutting. Moreover, $80.0 \%$ of women reported needing language assistance at the time of their health assessment.

Conclusions: Refugee women and girls experience high levels of trauma and persecution, suggesting the need for trauma-informed care. Those working with refugee women, such as resettlement agencies and health providers, should be equipped with information about antenatal care, nutrition, and pregnancy to newly arrived women. Lastly, differences in health status by region of origin indicate a need for tailored interventions and linguistically appropriate health information.
\end{abstract}

Keywords: Refugee, Health status, Region of origin, Women, Girls, Female, Trauma

\section{Background}

According to the United Nations High Commissioner for Refugees (UNHCR), over 65 million people were forced to flee their homes in 2015-- an unprecedented number that is reflective of broader political and social turmoil occurring globally [1]. This includes over 21 million individuals with refugee status, with $54 \%$ of refugees from three countries: Syria, Afghanistan, and Somalia

\footnotetext{
*Correspondence: msudhinaraset@ucla.edu

${ }^{1} J$ onathan and Karin Fielding School of Public Health, University of California, Los Angeles, 650 Charles E Young Dr. S, Los Angeles, CA 90095, USA Full list of author information is available at the end of the article
}

[2]. In the United States (US), the total number of refugees admitted fluctuates with ongoing political priorities and global events, with one of the highest numbers reported recently in fiscal year 2016 when 84,995 refugees were admitted [3]. While this number has declined since 2017, refugees continue to be an important population in the US given that thousands will continue to resettle each year coming from diverse regions of the globe. Moreover, the screening and vetting process is intense, lasting an average of two years [4]. First, the UNHCR refers cases to be considered for resettlement to countries and provides background information. The US then

(C) The Author(s). 2019 Open Access This article is distributed under the terms of the Creative Commons Attribution 4.0 International License (http://creativecommons.org/licenses/by/4.0/), which permits unrestricted use, distribution, and 
screens and decides whether refugees are admitted based on a thorough vetting process that includes multiple government agencies, security databases, background checks, and in-person interviews [4]. Historically, the United States has admitted refugees from all regions of the world, including Asia, Africa, Europe, Latin America, and the Middle East. The numbers of refugees from particular countries vary greatly depending on current political and social events. For example, in the early 1990s, refugees coming from former Soviet countries increased in response to the collapse of the Soviet Union; meanwhile, between 2006 and 2016, the highest numbers of refugees came from Myanmar, Iraq, and Bhutan due to ongoing wars and political and religious persecution [3]. California, in particular, has historically received one of the largest number of refugees in the country, with approximately 5100 refugees $(9.3 \%$ of all new arrivals) in 2017 [5]. Newly arriving refugees in California represent an ethnically diverse group coming from all regions of the world, representing 85 countries and speaking more than 80 different languages [6]. The diversity of the refugee population contributes to California's cultural and social identity; yet it also provides unique challenges for service providers and agencies working with refugee groups.

Moreover, women and children are particularly vulnerable as they are disproportionately exposed to conflictrelated trauma in their country of origin and during migration [7]. Similar to men, newly arrived refugee women experience challenges related to: lack of knowledge about resources or protections available in the receiving country, language and cultural barriers, and unstable economic circumstances [8]. However, young women and girls experience increased vulnerability due to other factors including increased risk of sexual violence and trauma during the migration process [9], sexual trafficking, and increased needs related to obstetric and reproductive health care (i.e. pregnancies, miscarriages, abortion care, access to contraception, etc.) [9-12]. However, to our knowledge, there are no published results on the health status of refugee women and children.

This study makes use of a novel dataset to provide much needed information on refugee populations. The Refugee Act of 1980 passed by Congress mandated that all refugees entering the United States receive standardized medical care and earmarked federal funding for health services at the local and state levels. Consequently, California's Office of Refugee Health developed the Refugee Health Assessment Program (RHAP), a multi-faceted program that aims to provide refugees with culturally competent medical services. In 2013, the RHAP standardized its data monitoring systems by implementing an electronic database -the Refugee Health Information System (RHEIS). This manuscript leverages this novel dataset in order to help guide local program planning and policy decisions.

Resettlement and government agencies engage intensively with refugees at the point of and within one year of arrival, offering support services such as cash assistance, medical assistance, housing, and employment assistance. Given the significant heterogeneity in the refugee population in the US today, it is important to examine the health concerns among refugees from different regions of the world. Most research on refugees has been small-scale in nature or focused on specific refugee populations [13-15]. The social, political, and historical contexts unique to countries and regions of the world create diverging flows of refugee populations certain to impact health outcomes differently.

The objective of this manuscript is to present a health profile of newly arrived refugee women and girls using data from California between 2013 and 2017. Because this represents one of the first population-based data of refugee women and children in California, our specific objectives are to provide baseline information on demographic indicators, health status and health behaviors, and trauma and persecution experiences of refugee women and children entering California in their first 90 days of arrival.

\section{Methods \\ Data collection}

Post-arrival health assessment data were collected pursuant to the Refugee Health Assessment Program (RHAP). Health assessments are conducted over the course of two visits in the first 90 days following a refugee's arrival to one of the eleven refugee county clinics in California. The first visit involves a general medical evaluation that includes any current symptoms or concerns; past medical and obstetric history; a traumatic events assessment (only asked of individuals 16 and older); and a social history including lifestyle assessment asked of individuals 15 years and older (i.e. sexual practices, tobacco, alcohol, and drug use). Refugees receive a basic physical assessment at this visit, including vital signs, immunizations, and laboratory blood draws to screen for infectious diseases, micronutrient deficiencies, and chronic disease indicators and/or risk factors. The second visit includes more specific medical concerns, reviewing lab results, and a general physical exam.

All information collected over the course of these two visits is documented on the California Refugee Health Assessment (CRHA) form and entered into the Refugee Health Electronic Information System (RHEIS), an electronic database. A nurse practitioner or medical doctor fills out the health assessment form by paper and then is transferred to the RHEIS by an office staff. All clinics were trained on recording health indicators of interest and data entry into the RHEIS database. 


\section{Study population, data and measures}

In total, 14,060 women and girls who entered California between October 3, 2013 and February 15, 2017 initiated the health assessment. All underwent a full or partial medical assessment at a refugee clinic in one of 11 counties in California, representing all potential sites for health assessments in California. According to Centers for Disease Control (CDC) guidelines, all refugees are recommended to take a post-arrival health assessment. This reported data represents approximately $95 \%$ of all refugees entering California during this time, and is the most comprehensive datasets on refugees in the state [16]. For the analytic sample, we include only women and girls who completed the health assessment $(n=12,277)$. Additionally, because we were interested in the role of region of origin, we dropped individuals who had missing data on this indicator. We also dropped one person from Oceania region. In total, the analytic sample was 12,270.

Because this data represents monitoring and surveillance activities, there is a high degree of missing values. Table 1 includes a list of measures, reports missing data, and indicates which questions are asked of specific age groups. Demographic data were collected from all women and included entry status (refugee, asylum seekers, Special Immigrant Visas (SIVs), parolees, and victims of trafficking $(\mathrm{VOT}))$. In this paper, we refer to individuals who come as refugee, asylum seekers, SIV, parolees, and VOT as "refugees." Refugees are individuals who are unable or unwilling to return to their country of nationality due to persecution or a well-founded fear of persecution; asylees are those already in the US or at a port of entry who unable or unwilling to return to their country of nationality due to persecution or a well-founded fear of persecution; parolees are those who are allowed into the US for humanitarian reasons or that the entry of the individual is believed to be a significant public benefit; SIVs are individuals who worked for the United States in Iraq or Afghanistan as interpreters or providing other services; VOTs are individuals subjected to force, fraud or coercion for the purpose of sexual exploitation or forced labor [16]. Other demographic data included arrival year; age categories; whether an interpreter was needed to conduct the health assessment; parity (number of births); and whether an individual lived in another country prior to the US. Women were asked to indicate their countries of birth. Countries were then categorized into regions classified by the US State Department's Bureau of Population, Refugees, and Migration (PRM) [17]. Regions of origin include Africa, Europe/Central Asia, Southeast Asia, South Asia, and Latin America and the Caribbean.

Women were asked about their histories of trauma throughout their life. Measures of traumatic events included: 1) physical assault (e.g. being attacked, hit, slapped, beaten up); 2) weapon assault (e.g. being shot,
Table 1 Missing values for all variables

\begin{tabular}{|c|c|c|}
\hline Variable & Missing No. (\%) & Total \\
\hline Age categories & $3(0)$ & 12,270 \\
\hline Entry status & $0(0)$ & 12,270 \\
\hline Education categories & $1185(9.7)$ & 12,270 \\
\hline Interpreter needed & $0(0)$ & 12,270 \\
\hline Lived in another country prior to US & $0(0)$ & 12,270 \\
\hline Elevated glucose & $2562(20.9)$ & 12,270 \\
\hline Ever smoke ${ }^{a}$ & $65(0.7)$ & 8751 \\
\hline Current smoker $^{\mathrm{a}}$ & 8014 (91.6) & 8751 \\
\hline One alcohol drink ${ }^{\mathrm{a}}$ & $65(0.7)$ & 8751 \\
\hline Pregnant result ${ }^{a}$ & $2769(31.6)$ & 8751 \\
\hline Experience of spontaneous abortion ${ }^{a}$ & $2162(24.7)$ & 8751 \\
\hline Abortion in lifetime ${ }^{a}$ & $2577(29.4)$ & 8751 \\
\hline Gravida: number of pregnancies ${ }^{a}$ & $582(6.7)$ & 8751 \\
\hline Parity: number of births woman has had ${ }^{a}$ & $990(11.3)$ & 8751 \\
\hline Hep B surface antigen ${ }^{a}$ & $154(1.8)$ & 8751 \\
\hline Hep B core antibody ${ }^{a}$ & $2359(27)$ & 8751 \\
\hline Hep B surface antibody ${ }^{a}$ & $2415(27.6)$ & 8751 \\
\hline Hep $C^{a}$ & $1474(16.8)$ & 8751 \\
\hline$H_{I I}^{a}$ & $242(2.8)$ & 8751 \\
\hline Female genital cutting $^{a}$ & 925 (10.6) & 8751 \\
\hline Syphilis VDRL or RPR ${ }^{a}$ & $360(4.1)$ & 8751 \\
\hline Chlamydia $^{c}$ & $522(22.6)$ & 2313 \\
\hline Any trauma experience ${ }^{b}$ & $152(1.8)$ & 8563 \\
\hline Persecution ${ }^{b}$ & $186(2.2)$ & 8563 \\
\hline
\end{tabular}

Indicates specific age groups for which questions were asked: ${ }^{\mathrm{a}} \mathrm{Age} \geq 15$, $^{\mathrm{b}}$ Age $\geq 16$, ${ }^{\wedge}$ Age $\geq 16$ to Age $\leq 25$

stabbed, threated with a knife, gun, bomb, land mine); 3) sexual assault (e.g. rape, attempted rape, made to perform any type of sexual act through force or threat of harm); 4) captivity (e.g. being kidnapped, abducted, held hostage, prisoner of war, forced labor); 5) sudden violent death of a family member (e.g. homicide, suicide); 6) serious injury, harm, or death you caused to someone else; 7) sudden move or loss of home and possessions.

Reproductive health indicators include current pregnancy status, lifetime experience of miscarriages, abortion, and female genital cutting. Current pregnancy status was confirmed through a urinary pregnancy test (classified as yes/no). Miscarriages classified the number of spontaneous abortions that the woman has had. At the health assessment, women were also asked about the number of abortions she has had. Miscarriages and abortions were categorized as binary measures and classified as ever experience spontaneous abortion or abortion. Female genital cutting was either self-reported or in a subset of instances depending on the health center, 
Table 2 Demographics by Region of Birth

\begin{tabular}{|c|c|c|c|c|c|c|c|}
\hline & Region of & oirth & & & & & \\
\hline & $\begin{array}{l}\text { Africa } \\
\text { (Col \%) }\end{array}$ & $\begin{array}{l}\text { Southeast Asia } \\
\text { (Col \%) }\end{array}$ & $\begin{array}{l}\text { Europe/Central Asia } \\
(\mathrm{Col} \%)\end{array}$ & $\begin{array}{l}\text { Latin America and the } \\
\text { Caribbean (Col \%) }\end{array}$ & $\begin{array}{l}\text { South Asia } \\
(\mathrm{Col} \%)\end{array}$ & $\begin{array}{l}\text { Total } \\
\text { (Col \%) }\end{array}$ & $p$-value \\
\hline Total & $894(100)$ & $863(100)$ & $906(100)$ & $408(100)$ & $9199(100)$ & $12,270(100)$ & \\
\hline Age categories & & & & & & & 0.000 \\
\hline $0-5$ years & $110(12.3)$ & $85(9.8)$ & $151(16.7)$ & $13(3.2)$ & $1286(14)$ & $1645(13.4)$ & \\
\hline $6-14$ years & $243(27.2)$ & $144(16.7)$ & $152(16.8)$ & $44(10.8)$ & $1291(14)$ & $1874(15.3)$ & \\
\hline $15-24$ years & $183(20.5)$ & $161(18.7)$ & $138(15.2)$ & $121(29.7)$ & 1609 (17.5) & $2212(18)$ & \\
\hline $25-30$ years & $91(10.2)$ & 89 (10.3) & $92(10.2)$ & $61(15)$ & $1356(14.7)$ & $1689(13.8)$ & \\
\hline $31-45$ years & $178(19.9)$ & $240(27.8)$ & 175 (19.3) & $107(26.2)$ & $1797(19.5)$ & $2497(20.4)$ & \\
\hline 46-64 years & $73(8.2)$ & $131(15.2)$ & $133(14.7)$ & $53(13)$ & $1356(14.7)$ & $1746(14.2)$ & \\
\hline $65+$ years & $16(1.8)$ & $13(1.5)$ & $65(7.2)$ & $9(2.2)$ & $501(5.4)$ & $604(4.9)$ & \\
\hline Entry status & & & & & & & 0.000 \\
\hline Asylee & $183(20.5)$ & $538(62.3)$ & $75(8.3)$ & 137 (33.6) & $332(3.6)$ & $1265(10.3)$ & \\
\hline Special Immigrant Visa (SIV) & $0(0)$ & $24(2.8)$ & $18(2)$ & $6(1.5)$ & 2937 (31.9) & $2985(24.3)$ & \\
\hline Parolee & $0(0)$ & $0(0)$ & $0(0)$ & $178(43.6)$ & $0(0)$ & $178(1.5)$ & \\
\hline Refugee & $708(79.2)$ & $247(28.6)$ & $811(89.5)$ & $67(16.4)$ & $5922(64.4)$ & 7755 (63.2) & \\
\hline Victim of trafficking & $3(0.3)$ & $54(6.3)$ & $2(0.2)$ & $20(4.9)$ & $8(0.1)$ & $87(0.7)$ & \\
\hline Education categories & & & & & & & 0.000 \\
\hline None & $202(25.4)$ & $86(10.4)$ & $74(9.2)$ & $8(2.1)$ & 1055 (12.8) & $1425(12.9)$ & \\
\hline $1-7$ years & $308(38.7)$ & 195 (23.6) & $139(17.2)$ & $73(18.8)$ & $1960(23.7)$ & $2675(24.1)$ & \\
\hline $8-11$ years & $114(14.3)$ & $193(23.4)$ & $235(29.2)$ & $81(20.8)$ & $1295(15.7)$ & $1918(17.3)$ & \\
\hline $12-14$ years & 95 (11.9) & $198(24)$ & $215(26.7)$ & $137(35.2)$ & 2659 (32.2) & 3304 (29.8) & \\
\hline $15+$ years & $77(9.7)$ & $153(18.5)$ & $143(17.7)$ & $90(23.1)$ & $1300(15.7)$ & $1763(15.9)$ & \\
\hline Interpreter needed & & & & & & & 0.000 \\
\hline No & $301(33.7)$ & $268(31.1)$ & $64(7.1)$ & $121(29.7)$ & $1088(11.8)$ & $1842(15)$ & \\
\hline Yes & $593(66.3)$ & $595(68.9)$ & $842(92.9)$ & $287(70.3)$ & $8111(88.2)$ & $10,428(85)$ & \\
\hline Lived in another country prior to US & & & & & & & 0.000 \\
\hline No & $153(17.1)$ & $427(49.5)$ & $206(22.7)$ & $191(46.8)$ & $1492(16.2)$ & $2469(20.1)$ & \\
\hline Yes & $741(82.9)$ & $436(50.5)$ & 700 (77.3) & 217 (53.2) & 7707 (83.8) & $9801(79.9)$ & \\
\hline
\end{tabular}

physicians also performed a visual check if the patient consented [we are not able to tell from the data how many visual checks were performed].

\section{Analysis}

Univariate analyses were conducted on each variable to assess missing data and explore distributions of responses. Second, bivariate analyses were conducted for demographic characteristics and health outcomes by country of origin. We reported chi-2 statistics to determine statistical differences across regions of origin. All analyses were conducted using Stata 12MP.

\section{Ethical considerations}

Data from these analyses are exempt from ethical review because they are part of California Department of Public Health's routine data collection and monitoring activities as determined and reviewed by UCLA's Institutional Review Board.

\section{Results}

\section{Demographic characteristics}

Out of 12,279 female women and girls, $13.4 \%$ were between the ages of $0-5$ years, with more girls arriving from Europe/Central Asia and South Asia (16.7 and $14.0 \%$, respectively) compared to other regions. The majority of individuals enter as refugees (60.3\%), followed by $24.3 \%$ as Special Immigrant Visas (SIV), $10 \%$ of asylees, $1.5 \%$ as parolees, and $0.7 \%$ came as victims of trafficking (VOT) (see Table 2). The overwhelming majority of female refugees are from South Asia (73.9\%), followed by women from Southeast Asia (7.8\%), Africa (7.4\%), Latin America and the Caribbean (LAC) (4.4\%), and Europe/Central Asia (6.4\%). Moreover, 12.9\% reported 
no education, $24.1 \% 1-7$ years of education, $17.3 \% 8-11$ years, $29.8 \% 12-14$ years, and $15.9 \% 15+$ years of education. There were high levels of interpreters needed at the time of the health assessment (85.0\%). Female refugees from Europe/Central Asia were most likely to need interpreter services (92.9\%). Finally, 79.9\% of women overall reported living in a transit country before arriving in the US.

\section{Experiences of trauma and persecution by region of birth} Importantly, almost one out of three women (27.7\%) reported experiencing a traumatic event (Table 3). When looking across region, women from Africa and Latin America and the Caribbean have higher levels of trauma compared to other regions ( 44.5 and $41.2 \%$, respectively). Women from Africa reported high levels of trauma related to sudden move/loss of home (21.2\%), physical assault (17.0\%), captivity (11.7\%), sexual assault (10.5\%), and weapon assault (17.4\%). Women in Latin America and the Caribbean reported high levels of trauma related to assault including $28.4 \%$ of women reporting physical assault, $23.7 \%$ reporting weapon assault, and $17.0 \%$ reporting sexual assault.

Moreover, more than half of women and girls reported experiencing persecution in their countries (56.6\%). Southeast Asian refugees were most likely to report persecution (80.5\%), followed by refugees from Latin America and the Caribbean, Africa, South Asia, and Europe/Central Asia.

\section{Reproductive health indicators and infectious diseases by region of birth}

There were 8751 women aged 15 years and older who were asked questions pertaining to reproductive health (Table 4). The mean number of births women had was 3.3, with women from Southeast Asia reporting the highest mean number of children (4.3) and Africa reporting the lowest (2.5). Women from Africa were most likely to report having no children (47.0\%) compared to those from Europe/Central Asia (20.2). In total, 418 women reported being currently pregnant (7.0\%), 1252 (19.0\%) reported ever having a spontaneous abortion, and 531 (8.6\%) reported ever having an abortion. Surprisingly, $47.1 \%$ of women from Europe/Central Asia reported experiences of spontaneous abortion, much higher than other regions. Those from Southeast Asia (28.5\%) and Europe/Central Asia (22.8\%) were also more likely to report ever having an abortion. In the sample, $2.1 \%$ of women reported female genital cutting, with 145 out of 162 women from Africa region. One in three women from Africa reported female genital cutting.

In terms of screening tests, $1.2 \%$ of women were positive for Hepatitis B surface antigen and 1.3\% was positive for Hepatitis C. Only 17 people tested positive for HIV
(0.2\%), 32 tested positive for syphilis (0.4\%), and 23 tested positive for chlamydia (1.3\%). Eleven out of the 17 people who tested positive for HIV came from Africa and 23 out of the 32 women who tested positive for syphilis came from South Asia.

Among girls younger than 15 years of age, $0.6 \%$ had reported female genital cutting, with 13 out of the 14 girls coming from Africa (Table 5). In terms of screening tests, $0.4 \%$ were reactive to Hepatitis B surface antigen and $0.6 \%$ reactive to Hepatitis C. Only two girls tested positive for HIV, one from Africa and one from South Asia. Only three girls reported syphilis within their first 90 days of arrival to the California.

\section{Health risk behaviors by region of birth}

Among women aged 15 years and older, $8.5 \%$ had ever smoked (Table 6). The highest levels come from Latin America and the Caribbean with $11.1 \%$ of women indicating they had smoked. Less than $5 \%$ of women had ever drank alcohol. 5.8\% of women had elevated glucose levels.

\section{Discussion}

This study provides timely data for health professionals and policy makers on the health profile of refugee women and girls entering California from 2013 to 2017. The data is novel and unique information to help tailor health and social services for refugee women. One of the most striking results is the high levels of trauma and persecution among refugee women: almost one-third of women reported experiences of trauma and over half reported persecution. Across all regions, 15\% of women reported trauma due to loss of homes and sudden moves. Refugee women may experience this sudden life disruption for a number of reasons including civil wars, environmental disasters, and organized violence. Additionally, 3.5\% reported harming or killing someone else and $9.5 \%$ reported trauma due to a death of a family member. These results are in line with other studies among refugees that find high levels of mental health concerns, with variability across regions of origin. One study found that approximately $23 \%$ of refugee women from multiple regions of the globe experienced emotional distress [18], while another study among Cambodian refugees found that all participants had suffered a traumatic event, with $99 \%$ experiencing near-death due to starvation and $90 \%$ reporting a family or friend murdered [19]. Region of origin is likely to play a significant role in the levels of and types of trauma experienced.

We also note important regional differences in regards to trauma. Women from Africa and Latin America and the Caribbean reported the highest levels of trauma, specifically due to weapon assault, physical assault, and sexual assault. The findings that women from Latin America and the Caribbean report the 
Table 3 Experiences of trauma and persecution by Region of Birth

\begin{tabular}{|c|c|c|c|c|c|c|c|}
\hline & \multicolumn{7}{|c|}{ Region of Birth } \\
\hline & $\begin{array}{l}\text { Africa } \\
(\text { Col \%) }\end{array}$ & $\begin{array}{l}\text { Southeast Asia } \\
(\mathrm{Col} \%)\end{array}$ & $\begin{array}{l}\text { Europe/Central Asia } \\
(\mathrm{Col} \%)\end{array}$ & $\begin{array}{l}\text { Latin America and the } \\
\text { Caribbean (Col \%) }\end{array}$ & $\begin{array}{l}\text { South Asia } \\
\text { (Col \%) }\end{array}$ & $\begin{array}{l}\text { Total } \\
\text { (Col \%) }\end{array}$ & $p$-value \\
\hline Total & $523(100)$ & $611(100)$ & $593(100)$ & $342(100)$ & $6494(100)$ & $8563(100)$ & \\
\hline Any trauma experience & & & & & & & 0.000 \\
\hline No trauma & $287(55.5)$ & $490(81)$ & $496(84.2)$ & $197(58.8)$ & $4614(72.5)$ & $6084(72.3)$ & \\
\hline Any trauma experience & $230(44.5)$ & $115(19)$ & $93(15.8)$ & $138(41.2)$ & $1751(27.5)$ & $2327(27.7)$ & \\
\hline \multicolumn{8}{|l|}{ Specific type of trauma } \\
\hline Captivity & & & & & & & 0.000 \\
\hline No & $462(88.3)$ & $562(92)$ & $567(95.6)$ & $304(88.9)$ & $6052(93.2)$ & $7947(92.8)$ & \\
\hline Yes & $61(11.7)$ & $49(8)$ & $26(4.4)$ & $38(11.1)$ & $442(6.8)$ & $616(7.2)$ & \\
\hline Harm or killed others & & & & & & & 0.002 \\
\hline No & $509(97.3)$ & $597(97.7)$ & $581(98)$ & $320(93.6)$ & $6255(96.3)$ & $8262(96.5)$ & \\
\hline Yes & $14(2.7)$ & $14(2.3)$ & $12(2.0)$ & $22(6.4)$ & $239(3.7)$ & $301(3.5)$ & \\
\hline Death of a family member & & & & & & & 0.000 \\
\hline No & $449(85.9)$ & $588(96.2)$ & $562(94.8)$ & $296(86.5)$ & $5854(90.1)$ & 7749 (90.5) & \\
\hline Yes & $74(14.1)$ & $23(3.8)$ & $31(5.2)$ & $46(13.5)$ & $640(9.9)$ & $814(9.5)$ & \\
\hline Sudden move/loss of home & & & & & & & 0.000 \\
\hline No & $412(78.8)$ & $572(93.6)$ & $563(94.9)$ & $288(84.2)$ & 5432 (83.6) & $7267(84.9)$ & \\
\hline Yes & $111(21.2)$ & $39(6.4)$ & $30(5.1)$ & $54(15.8)$ & 1062 (16.4) & $1296(15.1)$ & \\
\hline Physical assault & & & & & & & 0.000 \\
\hline No & $434(83.0)$ & $553(90.5)$ & $539(90.9)$ & 245 (71.6) & $5929(91.3)$ & $7700(89.9)$ & \\
\hline Yes & 89 (17.0) & $58(9.5)$ & $54(9.1)$ & 97 (28.4) & $565(8.7)$ & $863(10.1)$ & \\
\hline Sexual assault & & & & & & & 0.000 \\
\hline No & 468 (89.5) & $592(96.9)$ & $581(98)$ & $284(83)$ & $6384(98.3)$ & 8309 (97) & \\
\hline Yes & 55 (10.5) & $19(3.1)$ & $12(2.0)$ & $58(17.0)$ & $110(1.7)$ & $254(3)$ & \\
\hline Weapon assault & & & & & & & 0.000 \\
\hline No & 432 (82.6) & $583(95.4)$ & 565 (95.3) & $261(76.3)$ & 6078 (93.6) & 7919 (92.5) & \\
\hline Yes & $91(17.4)$ & $28(4.6)$ & $28(4.7)$ & $81(23.7)$ & $416(6.4)$ & $644(7.5)$ & \\
\hline Persecution & & & & & & & 0.000 \\
\hline No & 164 (32.1) & 117 (19.5) & $473(80.7)$ & 98 (29.6) & $2783(43.8)$ & 3635 (43.4) & \\
\hline Yes & 347 (67.9) & $482(80.5)$ & 113 (19.3) & 233 (70.4) & 3567 (56.2) & $4742(56.6)$ & \\
\hline
\end{tabular}

Age $\geq 16$ for all observations

highest levels of violence (i.e. weapon, physical, and sexual assault) are in line with reports of a rise in unaccompanied minors to the US from parts of Latin America, specifically Honduras, El Salvador, and Guatemala [20]. The high number of unaccompanied minors raised international concern when children were forced to flee their homes due to violence and crime [21]. The three countries have witnessed a proliferation of gangs and drugs and report some of the highest homicide rates in the region. Reports suggest that children experienced death of family members, poverty, and recruitment into gangs, causing an influx of out-migration to the US [21].
Moreover, refugee women and girls from Latin America and the Caribbean and Africa also report high levels of sexual violence (17 and $10.5 \%$, respectively). Past studies find that women and girls are more vulnerable to sexual violence particularly prior to and during the migration process $[9,11,12]$. Our data suggests that approximately $80 \%$ of refugee women and girls lived in a transit country before entering the US. We do not have data on when these traumatic experiences occur, but past studies suggest that living in a transit country before entering the US resulted in higher risk of preterm birth [10]. In transit countries, young women are targeted for sexual exploitation due to unstable livelihoods and lack of protection. 
Table 4 Reproductive health indicators by Region of Birth (15+ years and older)

\begin{tabular}{|c|c|c|c|c|c|c|c|}
\hline & Region of $k$ & & & & & & \\
\hline & $\begin{array}{l}\text { Africa } \\
\text { (Col \%) }\end{array}$ & $\begin{array}{l}\text { Southeast Asia } \\
\text { (Col \%) }\end{array}$ & $\begin{array}{l}\text { Europe/Central Asia } \\
(\mathrm{Col} \%)\end{array}$ & $\begin{array}{l}\text { Latin America and the } \\
\text { Caribbean (Col \%) }\end{array}$ & $\begin{array}{l}\text { South Asia } \\
(\mathrm{Col} \%)\end{array}$ & $\begin{array}{l}\text { Total } \\
\text { (Col \%) }\end{array}$ & $p$-value \\
\hline Total & $541(100)$ & $634(100)$ & $603(100)$ & $351(100)$ & $6622(100)$ & $8751(100.0)$ & \\
\hline $\begin{array}{l}\text { Parity: number of births } \\
\text { woman has had }\end{array}$ & & & & & & & 0.000 \\
\hline 0 & $235(47)$ & $196(33.7)$ & $91(20.2)$ & $150(46)$ & 2005 (34) & 2677 (34.5) & \\
\hline 1 & $4(0.8)$ & $0(0)$ & $0(0)$ & $0(0)$ & $16(0.3)$ & $20(0.3)$ & \\
\hline 2 & $108(21.6)$ & $123(21.2)$ & $134(29.8)$ & $68(20.9)$ & $1380(23.4)$ & $1813(23.4)$ & \\
\hline $3+$ & $153(30.6)$ & $262(45.1)$ & $225(50)$ & $108(33.1)$ & $2503(42.4)$ & 3251 (41.9) & \\
\hline Mean (SD) & $2.5(3.3)$ & $4.3(4.3)$ & $3.8(3.4)$ & $2.9(3.8)$ & $3.2(3.5)$ & $3.3(3.5)$ & \\
\hline Pregnancy result & & & & & & & 0.000 \\
\hline Negative & $385(93.4)$ & $505(97.7)$ & 349 (93.8) & $262(94.2)$ & $4063(92.3)$ & $5564(93.0)$ & \\
\hline Currently Pregnant & $27(6.6)$ & $12(2.3)$ & $23(6.2)$ & $16(5.8)$ & $340(7.7)$ & $418(7.0)$ & \\
\hline $\begin{array}{l}\text { Experience of spontaneous } \\
\text { abortion }\end{array}$ & & & & & & & 0.000 \\
\hline No miscarriages & 389 (82.4) & $469(87.8)$ & $136(52.9)$ & $256(82.3)$ & 4087 (81.5) & 5337 (81.0) & \\
\hline Miscarriage & $83(17.6)$ & $65(12.2)$ & $121(47.1)$ & $55(17.7)$ & $928(18.5)$ & $1252(19.0)$ & \\
\hline Abortion in lifetime & & & & & & & 0.000 \\
\hline No & $441(96.7)$ & $378(71.5)$ & $122(77.2)$ & $266(87.5)$ & 4436 (93.8) & $5643(91.4)$ & \\
\hline Yes & $15(3.3)$ & $151(28.5)$ & $36(22.8)$ & $38(12.5)$ & $291(6.2)$ & $531(8.6)$ & \\
\hline Female genital cutting & & & & & & & 0.000 \\
\hline No & $337(69.9)$ & $554(99.5)$ & $516(99.6)$ & $331(99.4)$ & $5926(99.8)$ & 7664 (97.9) & \\
\hline Yes & $145(30.1)$ & $3(0.5)$ & $2(0.4)$ & $2(0.6)$ & $10(0.2)$ & $162(2.1)$ & \\
\hline Hep B surface antigen & & & & & & & 0.000 \\
\hline Non-reactive & $523(97.9)$ & $595(95.5)$ & $581(98.8)$ & 344 (99.4) & $6452(99.2)$ & 8495 (98.8) & \\
\hline Reactive & $11(2.1)$ & $28(4.5)$ & $7(1.2)$ & $2(0.6)$ & $54(0.8)$ & $102(1.2)$ & \\
\hline Hep C & & & & & & & 0.000 \\
\hline Non-reactive & 479 (96.8) & 469 (98.5) & $519(97)$ & 284 (99.6) & $5430(99)$ & 7181 (98.7) & \\
\hline Reactive & $16(3.2)$ & $7(1.5)$ & $16(3)$ & $1(0.4)$ & $56(1)$ & $96(1.3)$ & \\
\hline HIV & & & & & & & 0.000 \\
\hline Negative & 517 (97.9) & $622(100)$ & $590(100)$ & $340(99.1)$ & $6423(100)$ & 8492 (99.8) & \\
\hline Positive & $11(2.1)$ & $0(0)$ & $0(0)$ & $3(0.9)$ & $3(0)$ & $17(0.2)$ & \\
\hline Syphilis VDRL or RPR & & & & & & & 0.693 \\
\hline Non-reactive & $517(99.2)$ & $601(99.7)$ & $574(99.7)$ & $340(99.7)$ & 6327 (99.6) & 8359 (99.6) & \\
\hline Reactive & $4(0.8)$ & $2(0.3)$ & $2(0.3)$ & $1(0.3)$ & $23(0.4)$ & $32(0.4)$ & \\
\hline Chlamydia $^{a}$ & & & & & & & 0.000 \\
\hline Negative & $136(99.3)$ & $127(94.1)$ & $121(99.2)$ & 103 (93.6) & $1281(99.5)$ & $1768(98.7)$ & \\
\hline Positive & $1(0.7)$ & $8(5.9)$ & $1(0.8)$ & $7(6.4)$ & $6(0.5)$ & $23(1.3)$ & \\
\hline
\end{tabular}

Age $\geq 15$ for all observations

${ }^{\mathrm{a}} \mathrm{Age} \geq 16$ to Age $\leq 25$

Women may engage in transactional or survival sex, in exchange for food or protection [11].

Our study suggests that $7.0 \%$ of refugee women were pregnant within 90 days of arrivals. Resettlement agencies and health providers should be equipped with information about antenatal care, nutrition, and pregnancy to newly arrived women. The overall reported rate for having an abortion was $8.6 \%$ in our sample, much lower than the US where approximately $24 \%$ of women will have had an abortion by age 45 [22]. In this study, 19\% of women reported ever having a miscarriage. It should be noted that there was a particularly high level of 
Table 5 Screening tests by Region of Birth for Girls ( $<15$ years old)

\begin{tabular}{|c|c|c|c|c|c|c|c|}
\hline & \multicolumn{7}{|c|}{ Region of Birth } \\
\hline & $\begin{array}{l}\text { Africa } \\
\text { (Col \%) }\end{array}$ & $\begin{array}{l}\text { Southeast Asia } \\
\text { (Col \%) }\end{array}$ & $\begin{array}{l}\text { Europe/Central Asia } \\
\text { (Col\%) }\end{array}$ & $\begin{array}{l}\text { Latin America and the Caribbean } \\
(\mathrm{Col} \%)\end{array}$ & $\begin{array}{l}\text { South Asia } \\
\text { (Col \%) }\end{array}$ & $\begin{array}{l}\text { Total } \\
\text { (Col \%) }\end{array}$ & $p$-value \\
\hline Total & $353(100)$ & $229(100)$ & $303(100)$ & $57(100)$ & $2577(100)$ & $3519(100.0)$ & \\
\hline Hep B surface antigen & & & & & & & 0.175 \\
\hline Non-reactive & $341(98.8)$ & $206(100)$ & $245(99.6)$ & $50(100)$ & 2151 (99.7) & 2993 (99.6) & \\
\hline Reactive & $4(1.2)$ & $0(0)$ & $1(0.4)$ & $0(0)$ & $7(0.3)$ & $12(0.4)$ & \\
\hline Hep C & & & & & & & 0.818 \\
\hline Non-reactive & $285(99.3)$ & 87 (98.9) & $136(100)$ & $36(100)$ & 1519 (99.4) & 2063 (99.4) & \\
\hline Reactive & $2(0.7)$ & $1(1.1)$ & $0(0)$ & $0(0)$ & $9(0.6)$ & $12(0.6)$ & \\
\hline HIV & & & & & & & 0.547 \\
\hline Negative & $303(99.7)$ & $190(100)$ & $222(100)$ & $50(100)$ & $1883(99.9)$ & 2648 (99.9) & \\
\hline Positive & $1(0.3)$ & $0(0)$ & $0(0)$ & $0(0)$ & $1(0.1)$ & $2(0.1)$ & \\
\hline Female genital cutting & & & & & & & 0.000 \\
\hline No & $223(94.5)$ & $104(100)$ & $218(100)$ & $34(100)$ & $1713(99.9)$ & $2292(99.4)$ & \\
\hline Yes & $13(5.5)$ & $0(0)$ & $0(0)$ & $0(0)$ & $1(0.1)$ & $14(0.6)$ & \\
\hline Syphilis VDRL or RPR & & & & & & & 0.796 \\
\hline Non-reactive & $92(100)$ & $105(99.1)$ & $62(100)$ & $29(100)$ & 545 (99.6) & $833(99.6)$ & \\
\hline Reactive & $0(0)$ & $1(0.9)$ & $0(0)$ & $0(0)$ & $2(0.4)$ & $3(0.4)$ & \\
\hline
\end{tabular}

Age $<15$ for all observations

missing data for these two indicators. Because this is self-reported data, women may be seriously underreporting these experiences due to feelings of stigma and shame, or not knowing they were pregnant.

The ability to disaggregate data by region also highlights important differences across regions, including female genital cutting. Experiences of female genital cutting are well documented in Africa, and our data suggests that one in three women from Africa report this practice. FGC is higher among those older than 15 years old at $2.1 \%$ compared to $0.6 \%$ of girls younger than 15 years old. Data from Africa suggests that there is a trend towards curbing the practice among younger cohorts compared to older cohorts; however, poorly educated women remain vulnerable to these practices [23]. Reports in the US suggests a rise in female genital cutting, doubling in the past decade, and have attributed these trends to a rise in immigration from African countries [24]. Although much lower compared to Africa, there were ten cases of female genital cutting from South Asia. This is in line with other research that has documented the rising concerns of female genital cutting in the region [25]. There is an urgent need for resettlement agencies and health professionals working with refugee women to be educated on the social and cultural causes of female genital cutting.

In regard to screening tests for infectious diseases for women aged 15 years and older, there were 102 cases of hepatitis B and 96 cases of hepatitis C. Hepatitis B was highest among Southeast Asian refugees (4.1\%) as is corroborated by existing literature [26]. Additionally, there were only 17 cases of HIV, 32 cases of syphilis, and 23 cases of chlamydia. Practitioners working with refugee communities should be aware of knowledge and understanding of infectious diseases when counseling patients. This will impact adherence to treatment and compliance of long-term follow up care [27]. Long-term treatment is a complex process and building a trusting relationship where cultural values are respected is of utmost importance.

Overall, health risk behaviors were also quite low among refugee women and girls. For example, less than $9 \%$ had ever smoked, and $4.8 \%$ ever drank alcohol. In contrast, among women aged 35 years of age in the US, $24 \%$ had smoked cigarettes in the past 30 days and $13 \%$ of women reported heavy drinking in the past 30 days [28]. Moreover, 5.8\% had elevated glucose levels, with the highest levels from Europe/Central Asia and South Asia (8.7 and 6.3\%, respectively). These levels are lower compared to the US population, in which $9.4 \%$ of the population have diabetes [29], but higher compared to Iraqi refugees (aged $0-76+$ ) who reported $2.7 \%$ with diabetes [30]. These individuals should be carefully monitored as elevated glucose levels may be a sign of diabetes and lead to cardiovascular diseases and other chronic conditions. Lack of physical activity, access to nutritional foods, and low acculturation are diabetes risk factors for refugees [31]. 
Table 6 Health risk behaviors by Region of Birth

\begin{tabular}{|c|c|c|c|c|c|c|c|}
\hline & \multicolumn{7}{|c|}{ Region of Birth } \\
\hline & $\begin{array}{l}\text { Africa } \\
\text { (Col \%) }\end{array}$ & $\begin{array}{l}\text { Southeast Asia } \\
\text { (Col \%) }\end{array}$ & $\begin{array}{l}\text { Europe/Central Asia } \\
\text { (Col \%) }\end{array}$ & $\begin{array}{l}\text { Latin America and the Caribbean } \\
(\mathrm{Col} \%)\end{array}$ & $\begin{array}{l}\text { South Asia } \\
(\mathrm{Col} \%)\end{array}$ & $\begin{array}{l}\text { Total } \\
(\text { Col \%) }\end{array}$ & $p$-value \\
\hline Total $^{a}$ & $541(100)$ & $634(100)$ & 603 (100) & $351(100)$ & $6622(100)$ & $8751(100.0)$ & 0.000 \\
\hline \multicolumn{8}{|l|}{ Ever smoke ${ }^{a}$} \\
\hline No & $524(97.6)$ & $598(95.4)$ & $573(95.7)$ & $311(88.9)$ & $5943(90.4)$ & 7949 (91.5) & \\
\hline Yes & $13(2.4)$ & $29(4.6)$ & $26(4.3)$ & $39(11.1)$ & $630(9.6)$ & $737(8.5)$ & \\
\hline \multicolumn{8}{|l|}{ Current smoker ${ }^{a}$} \\
\hline No & $9(69.2)$ & $16(55.2)$ & $20(76.9)$ & $25(64.1)$ & $287(45.6)$ & $357(48.4)$ & 0.002 \\
\hline Yes & $4(30.8)$ & $13(44.8)$ & $6(23.1)$ & $14(35.9)$ & $343(54.4)$ & $380(51.6)$ & \\
\hline \multicolumn{8}{|c|}{ One alcohol drink ${ }^{\mathrm{a}}$} \\
\hline No & $526(98)$ & $583(93)$ & $573(95.7)$ & 310 (88.6) & 6277 (95.5) & $8269(95.2)$ & 0.000 \\
\hline Yes & $11(2)$ & $44(7)$ & $26(4.3)$ & $40(11.4)$ & $296(4.5)$ & $417(4.8)$ & \\
\hline \multicolumn{8}{|l|}{ Elevated glucose } \\
\hline Not elevated & $608(98.2)$ & $604(97.4)$ & $780(91.3)$ & $311(98.4)$ & $6840(93.7)$ & $9143(94.2)$ & 0.000 \\
\hline Elevated & $11(1.8)$ & $16(2.6)$ & $74(8.7)$ & $5(1.6)$ & 459 (6.3) & $565(5.8)$ & \\
\hline
\end{tabular}

${ }^{\mathrm{a} A g e} \geq 15$ years

This study has a number of limitations. First, there may be serious under-reporting of self-reported data including experiences of abortions, miscarriages, female genital cutting, trauma and persecution. Questions around trauma and persecution may result in recall bias as they are asked to recall back to their childhood. In particular, women may not report traumatic events because it may be difficult for women to recall these memories, while other events such as sexual violence might be stigmatizing. Therefore, these are conservative estimates. Additionally, because visual checks were only performed in a few instances for female genital cutting, this study is not able to report on specific numbers of methods used. Additionally, while all clinics received training on the RHEIS system and questions, clinics may vary in terms of their reporting. There was also significant missing data, which is typical of routine monitoring data platforms. Moreover, while this paper provides data on female refugees, future analyses should link data of children to their parents to assess the role of family units on children's health outcomes. As a subset of this research, unaccompanied minors are a particularly critical issue for public health practitioners.

\section{Conclusions}

This study bridges existing gaps in the literature, including lack of population-based data on female refugee health, by providing an up-to-date general health status of refugee women and girls from many countries who arrived in California, the highest receiving state of refugees in the US. The data includes over 14,000 female refugees and is one of the first population-based datasets of refugee women and girls in the US; thus allowing comparisons across regions and health outcomes. Additionally, this study is quantitative in nature, producing a much larger dataset than previous qualitative studies on this population. To our knowledge, this is the first study to present California population-based data on experiences of trauma and persecution, reproductive health indicators, screening tests, and health risk behaviors by region of origin.

There are a number of programmatic recommendations for agencies and service providers working with refugee women and girls. These data support the growing need for trauma-informed care, or the need to recognize and respond to the widespread impact of trauma. Principles of a trauma-informed approach include safety, trustworthiness and transparency, peer support, collaboration and mutuality, empowerment voice and choice, and cultural, historical and gender identities [32]. This approach works with patients and their families in a way that is empowering and focuses on the relationship between trauma and symptoms of trauma such as depression, anxiety, and substance use. The effects of trauma may be particularly long-lasting for children [33], and interventions are needed specifically with child and adolescent populations.

Patients should also be informed of treatment guidelines and health information in a language that women can understand. In our sample, over $80 \%$ of refugee women needed interpreters at the time of their health assessment. Language barriers and inadequate communication in the healthcare setting may have significant consequences, including delayed care, lower use of preventive services, less adherence to treatment [34], lower prenatal care utilization and lower quality care [35]. 
This data highlights the need for ongoing routine data collection and health assessments, including longitudinal data that links to long-term outcomes. Particularly for indicators such as infectious diseases, local jurisdictions should have access to data in order to promptly diagnose and treat patients for potentially long-term illnesses. Understanding the unique health challenges of refugee women and girls will ultimately help agencies and health providers support this population in obtaining quality and appropriate care.

\section{Abbreviations}

CDC: Centers for Disease Control; CRHA: California Refugee Health Assessment; PRM: Population, Refugees, and Migration; RHAP: Refugee Health Assessment Program; RHEIS: Refugee Health Information System; SIVs: Special Immigrant Visas; UNHCR: United Nations High Commissioner for Refugees; VOT: Victims of Trafficking

\section{Acknowledgements}

We would like to thank the Refugee Health Programs from the local health jurisdictions for their dedication and hard work. They not only provide the necessary medical screening but also the data for this publication. We would also like to acknowledge the funding agency, the Office of Refugee Resettlement. Lastly, we would like to thank Suba Narasimhan and Francesca Cameron for assistance with references.

\section{Authors' contributions}

MS analyzed data and led the writing of the manuscript. NC and MR contributed to writing, oversaw data collection, and interpretation of the data. All authors read and approved the final manuscript.

\section{Funding}

This work is funded by the Office of Refugee Resettlement. The funders had no role in the design of the study and collection, analysis, and interpretation of data and in writing the manuscript should be declared.

\section{Availability of data and materials}

The datasets generated and/or analysed during the current study are not publicly available due to additional ongoing analyses, but are available from the corresponding author on reasonable request.

\section{Ethics approval and consent to participate}

Data from these analyses are exempt from ethical review because they are part of California Department of Public Health's routine data collection and monitoring activities as determined and reviewed by UCLA's Institutional Review Board.

\section{Consent for publication}

Not applicable.

\section{Competing interests}

The authors declare that they have no competing interests.

\section{Author details \\ 'Jonathan and Karin Fielding School of Public Health, University of California, Los Angeles, 650 Charles E Young Dr. S, Los Angeles, CA 90095, USA. ${ }^{2}$ Office of Refugee Health, Center for Infectious Disease, California Department of Public Health, 1616 Capitol Ave, Sacramento, CA 95899, USA.}

Received: 17 July 2019 Accepted: 30 September 2019 Published online: 16 October 2019

\section{References}

1. UNHCR UNHC for. Global forced displacement hits record high [Internet]. UNHCR. 2016 [cited 2016 Aug 30]. Available from: http://www.unhcr.org/en-us/news/ latest/2016/6/5763b65a4/global-forced-displacement-hits-record-high.html

2. UNHCR UNHC for. Figures at a Glance [Internet]. UNHCR. 2016 [cited 2016 Aug 30]. Available from: http://www.unhcr.org/en-us/figures-at-a-glance.html
3. Igielnik R, Krogstad J. Where refugees to the U.S. come from [Internet]. Pew Research Center; 2017 [cited 2019 Jul 22]. Available from: https://www. pewresearch.org/fact-tank/2017/02/03/where-refugees-to-the-u-s-come-from/

4. Refugee Processing and Security Screening [Internet]. USCIS. 2018 [cited 2019 Sep 17]. Available from: https://www.uscis.gov/refugeescreening

5. Migration Policy Institute. Refugees and Asylees in the United States [Internet]. migrationpolicy.org. 2015 [cited 2016 Sep 2]. Available from: http://www.migrationpolicy.org/article/refugees-and-asylees-united-states

6. Office of Refugee Health: Program Overview [Internet]. 2018 [cited 2018 Mar 9]. Available from: https://www.cdph.ca.gov/Programs/CID/ORH/Pages/ Program\%200verview.aspx

7. Kurth E, Jaeger FN, Zemp E, Tschudin S, Bischoff A. Reproductive health care for asylum-seeking women - a challenge for health professionals. BMC Public Health. 2010;10(1):659.

8. Stewart DE, Gagnon AJ, Merry LA, Dennis C-L. Risk factors and health profiles of recent migrant women who experienced violence associated with pregnancy. J Womens Health. 2012:21(10):1100-6.

9. United Nations High Commissioner for Refugees. Refugee women and children face heightened risk of sexual violence amid tensions and overcrowding at reception facilities on Greek islands [Internet]. UNHCR. 2018 [cited 2018 Mar 9]. Available from: http://www.unhcr.org/news/ briefing/2018/2/5a7d67c4b/refugee-women-children-face-heightened-risksexual-violence-amid-tensions.html

10. Wanigaratne S, Cole DC, Bassil K, Hyman I, Moineddin R, Urquia ML. The influence of refugee status and secondary migration on preterm birth. J Epidemiol Community Health. 2016. https://doi.org/10.1136/jech-2015-206529.

11. Lehmann A. Safe abortion: a right for refugees? Reprod Health Matters. 2002;10(19):151-5.

12. Burns $K$, Male S, Pierotti D. The reproductive health of refugees. Int Fam Plan Perspect [Internet]. 2000 [cited 2019 Feb 22];26. Available from: https:// search.proquest.com/openview/465ecc90f50d14bcf112eaef27ee3b36/1?cbl= 51907\&pq-origsite $=$ gscholar

13. Perera S, Gavian M, Frazier P, Johnson D, Spring M, Westermeyer J, et al. A longitudinal study of demographic factors associated with stressors and symptoms in African refugees. Am J Orthop. 2013;83(4):472-82.

14. Gann P, Nghiem L, Warner S. Pregnancy characteristics and outcomes of Cambodian refugees. Am J Public Health. 1989;79(9):1251-7.

15. Beiser M, Hou F. Language acquisition, unemployment and depressive disorder among southeast Asian refugees: a 10-year study. Soc Sci Med. 2001;53(10):1321-34.

16. Office of Refugee Health. Report on Refugee Health in California: Federal Fiscal Year 2015. Sacramento: California Department of Public Health; 2015.

17. Department Of State. The Office of Website Management B of PA. Refugee Admissions Statistics [Internet]. 2012 [cited 2016 Sep 9]. Available from: http://www.state.gov/j/prm/releases/statistics/index.htm

18. Johnson-Agbakwu CE, Allen J, Nizigiyimana JF, Ramirez G, Hollifield M. Mental health screening among newly arrived refugees seeking routine obstetric and gynecologic care. Psychol Serv. 2014;11(4):470-6.

19. Marshall GN, Schell TL, Elliott MN, Berthold SM, Chun C-A. Mental health of Cambodian refugees 2 decades after resettlement in the United States. JAMA. 2005;294(5):571-9.

20. Southwest Border Unaccompanied Alien Children FY 2014 | U.S. Customs and Border Protection [Internet]. 2014 [cited 2018 Mar 27]. Available from: https://www.cbp.gov/newsroom/stats/southwest-border-unaccompaniedchildren/fy-2014

21. Ciaccia KA, John RM. Unaccompanied immigrant minors: where to begin. J Pediatr Health Care. 2016;30(3):231-40.

22. Jones RK, Jerman J. Population group abortion rates and lifetime incidence of abortion: United States, 2008-2014. Am J Public Health. 2017;107(12):1904-9.

23. Van Rossem R, Meekers D, Gage AJ. Trends in attitudes towards female genital mutilation among ever-married Egyptian women, evidence from the Demographic and Health Surveys, 1995-2014: paths of change. Int J Equity Health [Internet]. 2016 Feb 24 [cited 2018 Mar 27];15. Available from: https://www.ncbi.nlm.nih.gov/pmc/articles/PMC4765026/

24. Feldman-Jacobs C, Clifton D. Female Genital Mutilation/Cutting: United States Government's Response | Fact Sheet | U.S. Agency for International Development [Internet]. 2014 [cited 2016 Aug 30]. Available from: https:// www.usaid.gov/news-information/fact-sheets/female-genital-mutilationcutting-usg-response

25. Rashid A, lguchi Y. Female genital cutting in Malaysia: a mixed-methods study. BMJ Open. 2019;9(4):e025078. 
26. Walker PF, Jaranson J. Refugee and immigrant health care. Med Clin North Am. 1999;83(4):1103-20 viii.

27. Jackson JC, Rhodes LA, Inui TS, Buchwald D. Hepatitis B among the Khmer. Issues of translation and concepts of illness. J Gen Intern Med. 1997;12(5):292-8,

28. Merline AC, O'Malley PM, Schulenberg JE, Bachman JG, Johnston LD. Substance use among adults 35 years of age: prevalence, adulthood predictors, and impact of adolescent substance use. Am J Public Health. 2004;94(1):96-102.

29. Statistics About Diabetes |ADA [Internet]. [cited 2019 Sep 20]. Available from: https://www.diabetes.org/resources/statistics/statistics-about-diabetes

30. Yanni EA, Naoum M, Odeh N, Han P, Coleman M, Burke H. The health profile and chronic diseases comorbidities of US-bound Iraqi refugees screened by the International Organization for Migration in Jordan: 2007-2009. J Immigr Minor Health. 2013;15(1):1-9.

31. Jaber LA, Brown MB, Hammad A, Zhu Q, Herman WH. Lack of acculturation is a risk factor for diabetes in Arab immigrants in the US. Diabetes Care. 2003;26(7):2010-4.

32. Baylor C. Trauma-Informed Approach and Trauma-Specific Interventions [Internet]. 2014 [cited 2018 Mar 26]. Available from: https://www.samhsa gov/nctic/trauma-interventions

33. Fazel M, Reed RV, Panter-Brick C, Stein A. Mental health of displaced and refugee children resettled in high-income countries: risk and protective factors. Lancet. 2012;379(9812):266-82.

34. Flores G. Language barriers to health Care in the United States. N Engl J Med. 2006;355(3):229-31.

35. Sherraden MS, Barrera RE. Prenatal care experiences and birth weight among Mexican immigrant women. J Med Syst. 1996;20(5):329-50.

\section{Publisher's Note}

Springer Nature remains neutral with regard to jurisdictional claims in published maps and institutional affiliations.

Ready to submit your research? Choose BMC and benefit from:

- fast, convenient online submission

- thorough peer review by experienced researchers in your field

- rapid publication on acceptance

- support for research data, including large and complex data types

- gold Open Access which fosters wider collaboration and increased citations

- maximum visibility for your research: over $100 \mathrm{M}$ website views per year

At $\mathrm{BMC}$, research is always in progress.

Learn more biomedcentral.com/submissions 